\title{
Ultrastructural description of Ceratomyxa tenuispora (Myxozoa), a parasite of the marine fish Aphanopus carbo (Trichiuridae), from the Atlantic coast of Madeira Island (Portugal)
}

\author{
Graça Casal $^{1,2,3}$, Graça Costa ${ }^{4}$ and Carlos Azevedo ${ }^{1,2}$ \\ ${ }^{1}$ Department of Cell Biology, Institute of Biomedical Sciences (ICBAS/UP), University of Porto, Lg. A. Salazar no. 2 , \\ P-4099-003 Porto, Portugal; \\ ${ }^{2}$ Laboratory of Pathology, CIIMAR/UP, University of Porto, Rua dos Bragas no. 117, P-4050-123 Porto, Portugal; \\ ${ }^{3}$ Department of Sciences, High Institute of Health Sciences, P-4585-116 Gandra, Portugal; \\ ${ }^{4}$ Centre for Macaronesian Studies (CEM), University of Madeira, P-9000-390 Funchal, Portugal
}

Key words: Myxozoa, Ceratomyxa tenuispora, parasite, marine fish, Aphanopus carbo, ultrastructure

\begin{abstract}
The first ultrastructural description of Ceratomyxa tenuispora Kabata, 1960 (Myxozoa, Bivalvulida) from Madeira Island (Portugal), a parasite found in the gall bladder of the commercially important black-scabbard fish, Aphanopus carbo Lowe is presented. This parasite possesses spherical to ellipsoidal disporous trophozoites. Spores have a central crescent-shaped body averaging $11.0 \mu \mathrm{m}$ in length, $28.5 \mu \mathrm{m}$ in thickness and $12.1 \mu \mathrm{m}$ in width. The valves have two long opposite lateral processes (ribbon-like structures or tails), each averaging $173 \mu \mathrm{m}$ in length. The total thickness of the spore averages $375 \mu \mathrm{m}$. The spore has two sub-spherical polar capsules $(\sim 5.2 \times 4.1 \mu \mathrm{m})$, each with a polar filament with 7 to 8 coils. Some ultrastructural aspects of the sporogonic stages are described. The trophozoites develop without contact with epithelial cells. The cytoplasmic membrane has numerous evenly distributed external slender projections about 0.3 to $0.7 \mu \mathrm{m}$ long. The sporogenesis produces two spores without pansporoblast formation. In the matrix of the capsular primordium, microtubules with an unusual organisation were observed. A binucleate sporoplasm that contains several sporoplasmosomes and dense bodies fills the spore cavity and extends to the tails without penetrating them.
\end{abstract}

The genus Ceratomyxa Thélohan, 1892 is one of the largest genera of Myxosporea (phylum Myxozoa), which includes about 172 species, mostly parasites of marine fish (Lom and Dyková 2006). Most of them are coelozoic, rarely histozoic. They have a world-wide distribution and cause severe infections, mainly of the digestive tract organs (for revision see Lom and Dyková 1992, Eiras 2006). Only some species were ultrastructurally studied, such as C. shasta (Yamamoto and Sanders 1979), C. globulifera (Desportes and Théodoridès 1982), Ceratomyxa sp. hyperparasitized with the microsporidian Nosema ceratomyxae (Diamant and Paperna 1989), C. labracis and C. diplodae (Alvarez-Pellitero and Sitjà-Bobadilla 1993, Sitjà-Bobadilla and AlvarezPellitero 1993a), C. sparusaurati (Sitjà-Bobadilla et al. 1995, Palenzuela et al. 1997), C. drepanopsettae (Morrison et al. 1996), and C. protopsettae (Cho et al. 2004).

Ceratomyxa tenuispora Kabata, 1960 was described from the black-scabbard fish, Aphanopus carbo Lowe based only on a schematic drawing (Kabata 1960). Later, this parasite was reported from the same fish host, a commercially important fish species, collected from deep-waters around Madeira Island (Costa et al. 1996). The present paper details the ultrastructure of the spores and some sporogonic stages of the life cycle of Ceratomyxa tenuispora are described.

\section{MATERIALS AND METHODS}

One hundred and one specimens of black-scabbard fish, Aphanopus carbo Lowe (Teleostei, Trichiuridae) (specimens from 100 to $130 \mathrm{~cm}$ long), were collected at depths of 600 1,200 meters and at 5 to 10 miles off the North Atlantic coast of Madeira Island $\left(33^{\circ} 07^{\prime}-32^{\circ} 02^{\prime} \mathrm{N}, 16^{\circ} 16^{\prime}-17^{\circ} 16^{\prime} \mathrm{W}\right)$. Immediately after capture, fish were placed on ice and brought to the laboratory for parasitological examination. After necropsy, the gall bladders were removed and examined for infections with myxosporeans by light microscopy (LM). Wet smears revealed myxosporean spores and other life-cycle stages in the bile. Fresh isolated mature spores were observed using differential interference contrast (DIC) (Nomarski) optics. For transmission electron microscopy (TEM), small fragments of parasitized gall bladders as well as bile fluid were fixed in 3\% glutaraldehyde in $0.2 \mathrm{M}$ sodium cacodylate buffer ( $\mathrm{pH} 7.2)$ for $10 \mathrm{~h}$ at $4^{\circ} \mathrm{C}$, concentrated in agar and then washed overnight in the same buffer at $4^{\circ} \mathrm{C}$. The samples were postfixed with $2 \%$ osmium tetroxide in the same buffer for $2 \mathrm{~h}$ at $4^{\circ} \mathrm{C}$, dehydrated through an ascending ethanol and propylene oxide series, and embedded in Epon. Semithin sections for LM observations were stained with methylene blue-Azur II. Ultrathin sections were double-stained with uranyl acetate and lead citrate before observation in a JEOL 100 CXII TEM, operated at $60 \mathrm{kV}$. 


\section{RESULTS}

Disporous plasmodia of spherical to ellipsoidal shape (Fig. 1) and spores (Fig. 2) were found floating in the bile of several fish ( 7 out of 12). The body of the isolated mature spores was $11.0 \pm 0.9 \mu \mathrm{m}(\mathrm{n}=15)$ long by $28.5 \pm 1.2 \mu \mathrm{m}(\mathrm{n}=12)$ thick and $12.1 \pm 1.1 \mu \mathrm{m}$ wide in sutural view. The spore body was crescent-shaped in front view with a convex anterior end and a flattened posterior one (Fig. 2). Two polar capsules were equal, sub-spherical to pyramidal, and measured $5.2 \pm 0.3 \mu \mathrm{m}$ $\times 4.1 \pm 0.4(\mathrm{n}=10) \mu \mathrm{m}$ (Fig. 2). The spore had two smooth symmetrical valves that were prolonged by two fine long, opposite lateral processes (ribbon-like projections or tails) which tapered gradually towards the tips, each one of $173.2 \pm 6.3 \mu \mathrm{m}(\mathrm{n}=30)$ in length. Total dimension of the tailed spore was $375.5 \pm 17.1 \mu \mathrm{m}(\mathrm{n}=$ $15)$, ranking the spore as one of the largest among myxosporeans (Fig. 2).

\section{Ultrastructural observations}

The earliest stages observed were uninucleate cells measuring 12.7-19.5 $\mu \mathrm{m}$ in diameter, whose nuclei presented a prominent nucleolus. Rounded trophozoites were both free-floating or joined to each other beadslike, and their cytoplasm contained a variable number of secondary cells. Neither contact with epithelial cells of the gall bladder nor pansporoblast formation was observed (Fig. 3). The cytoplasm of the primary cell contained mitochondria, scattered ribosomes and several membranous structures similar to small vesicles with a matrix of heterogeneous content (Figs. 3, 4). Cytoplasmic membrane of the primary cells contained, at the periphery, several external slender projections basally attached to the surface. These had a uniform shape and variable length ranging from 0.3 to $0.7 \mu \mathrm{m}$, and were evenly distributed throughout the plasmodia surface (Figs. 3, 4).

Immature spores were easily identified in early sporoblasts by their valvogenic, capsulogenic and sporoplasmic cells (Fig. 5). Valvogenic cells, which were joined in suture line by a continuous septate junction, occupied an external position relative to other sporogenic cells (Figs. 5, 8, 9, 13). Their external plasmalemma was smooth and dense and the internal one was thin and showed an irregular outline in close contact with other inner spore cells (Figs. 10, 13, 15). During early sporogenic phase, the valvogenic cells gradually differentiated to form two long tails surrounding the spore body. Initially those extensions of the valvogenic cells were dilated (Fig. 5) and later they modified to ribbon-shaped (Figs. 8, 10, 11, 14). The cytoplasm of the valvogenic cells in mature spores appeared to contain only small vesicles (Figs. 5, 10, 11, 14).

During the early differentiation of the capsulogenic cells, the spherical capsular primordium was prolonged by the external tube. Before the inversion of the external tube, microtubules with an unusual organisation were observed in the matrix of the capsular primordium. A larger aggregate with hundreds of microtubules was grouped in several bundles and these were arranged in different orientations (Figs. 6, 7).

In mature spores the nuclei persisted until completion of the capsulogenesis (Fig. 8) and the polar capsules had a polar filament with a basal straight central shaft and coils of 7 to 8 turns (Figs. 5, 8, 12). Polar capsules consisted of a thin electron-dense external wall and a thicker and lighter inner one (Figs. 12, 13). The apical channel for the polar filament discharge showed close contact with valves (Figs. 12, 13).

The sporoplasm was located in the posterior end of the spore and the cytoplasm contained two nuclei close to each other, mitochondria, ribosomes, cisternae of endoplasmic reticulum and several sporoplasmosomes. These spherical-shaped vesicles were membranebounded and contained an electron-dense and homogenous matrix (Figs. 10, 14, 15). The sporoplasm filled the spore cavity and extended to the tails, without penetrating them (Figs. 8, 10, 15). A schematic drawing of the spore, based on LM and TEM observations, is shown in Fig. 16.

\section{DISCUSSION}

The ultrastructural observations of the sporogenesis and consequently of the spores of Ceratomyxa tenuispora Kabata, 1960 showed several similarities to species from the family Ceratomyxidae Doflein, 1899 (Lom and Dyková 1992). This species is ultrastructurally described for the first time in the present study.

Cytoplasmic extensions of the outer plasmodial membrane have usually been described in coelozoic parasites of various genera found in gall bladder and they are closely correlated with the type of nutrition (Sitjà-Bobadilla and Alvarez-Pellitero 1993b). Ceratomyxa protopsettae trophozoites are attached to the epithelial cells by short or long finger-like projections (Cho et al. 2004); ramified microvillus-like projections of different sizes were described in Zschokkella icterica (Diamant and Paperna 1992). Long finger-like pseudopodial projections reaching a length of about $5 \mu \mathrm{m}$ were described in Zschokkella mugilis (Sitjà-Bobadilla and Alvarez-Pellitero 1993b). A similar interaction was observed in Myxidium trachinorum, which contacts the epithelium of the gall bladder through two to three filose processes (Canning et al. 1999). At one end of some primary cells, rhizoid-like projections were observed in Ceratomyxa sparusaurati (Sitjà-Bobadilla et al. 1995). Unlike in this last species, in C. tenuispora we did not see any contact with epithelial cells of the gall bladder and the shape and distribution of the cytoplasmic projections found in $C$. tenuispora show some ultrastructural differences. 

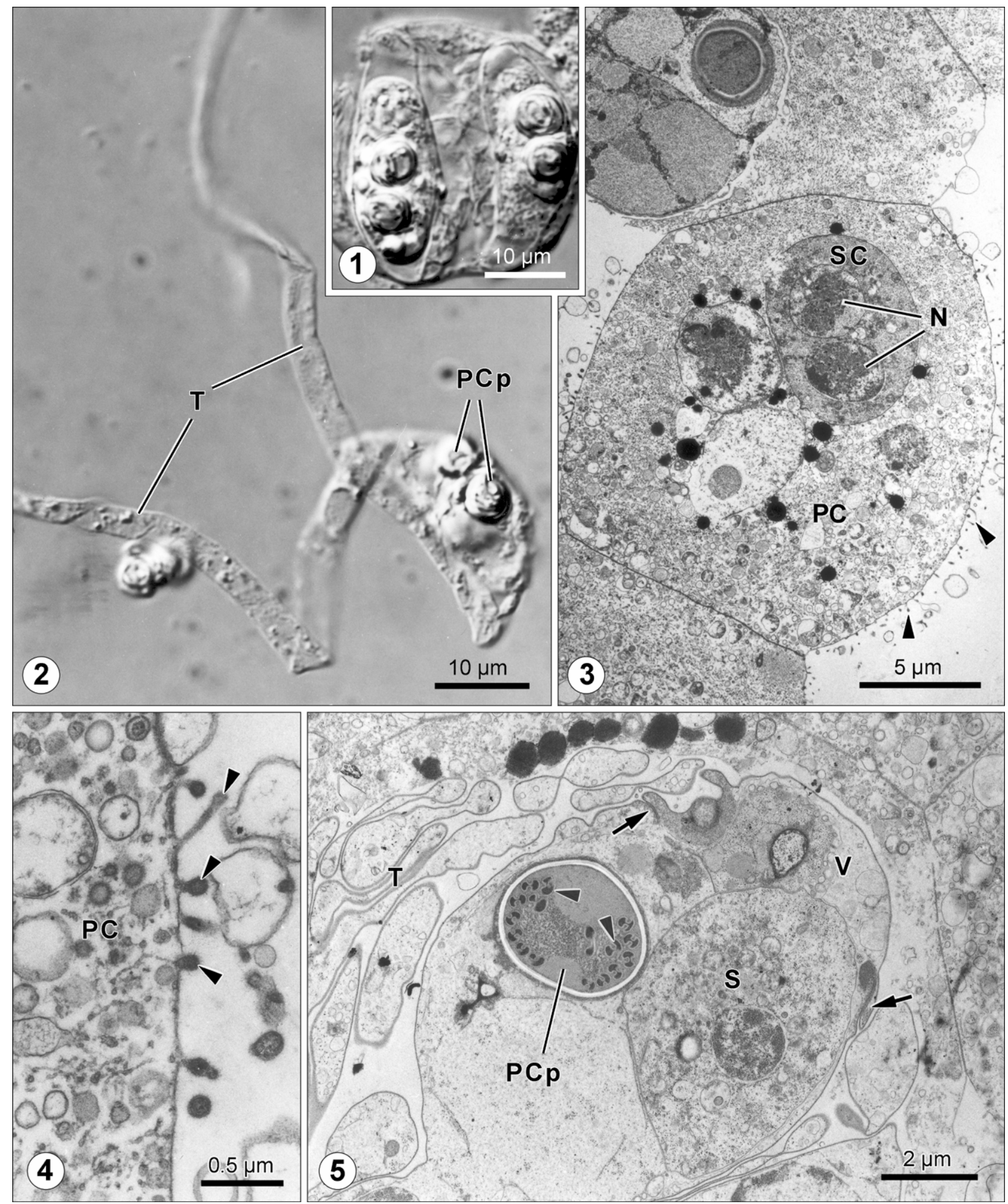

Figs. 1-5. Ceratomyxa tenuispora, DIC (Figs. 1, 2) and transmission electron micrographs (Figs. 3-5). Fig. 1. Fresh disporous plasmodium. Fig. 2. Free mature spore showing two polar capsules (PCp) and two long tapering lateral opposite tails (T). Fig. 3. A secondary cell (SC) with two nuclei (N) within a primary cell (PC) containing several slender projections (arrowheads). Fig. 4. Detail of the periphery of the primary cell (PC) showing several slender projections (arrowheads). Fig. 5. Spore showing a polar capsule (PCp) with different sections of the polar filament (arrowheads), a sporoplasm (S) and valvogenic cells (V) with the suture line (arrows). At the periphery, several sections of tails (T) can be observed. 

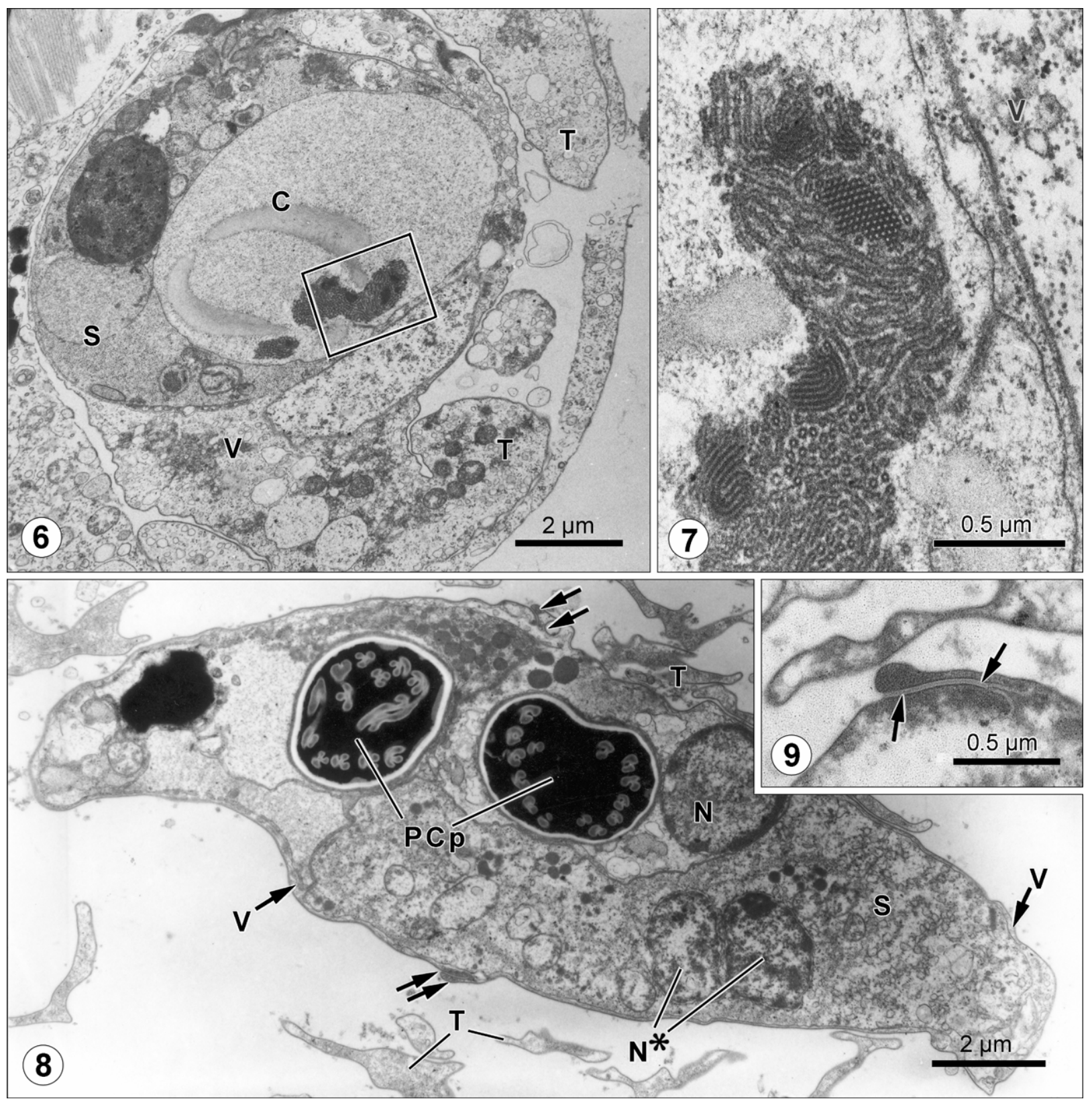

Figs. 6-9. Transmission electron micrographs of Ceratomyxa tenuispora. Fig. 6. A spore showing the valves (V), several sections of their two tails (T), the capsular primordium (C) containing a well-organized cluster of microtubules (boxed area) and the sporoplasm (S). Fig. 7. Detail of the cluster of microtubules (boxed area in Fig. 6). At the periphery, valvogenic cell (V). Fig. 8. Longitudinal section of a spore showing one nucleus $(\mathrm{N})$ of a capsulogenic cell, two polar capsules (PCp), and the binucleate $\left(\mathrm{N}^{*}\right)$ sporoplasm (S). Valvogenic cells (V) are reduced to a thin layer in close contact with internal cells. Sutures (double arrows) between the valves can be seen. Some tail sections (T) can be seen at the periphery of the spore. Fig. 9. Detail of the continuous septate junction of the suture line.

Ultrastructural description concerning the polar capsule differentiation referred to the presence of unusual structures inside the capsular primordium, such as globule of electron-dense material (Lom 1969), concentric structure (Lom et al. 1989) or the differentiation of the microfilament-like structures (Casal et al. 2002). Bundles of tubuli in the capsular matrix were reported in the polar capsules of mature spores in some genera, such as Sphaeromyxa (Lom 1969), Henneguya (Rocha et al.
1992) and Myxobolus (Casal et al. 2002). In the cytoplasm of the capsulogenic cells, microtubules are regularly seen around the external tube interpreted to provide the mechanic force needed for its inversion into the capsular primordium (Current 1979). We reported the presence of several microtubular bundles inside the capsular matrix before the inversion of the external tube which apparently also contributes to that. 

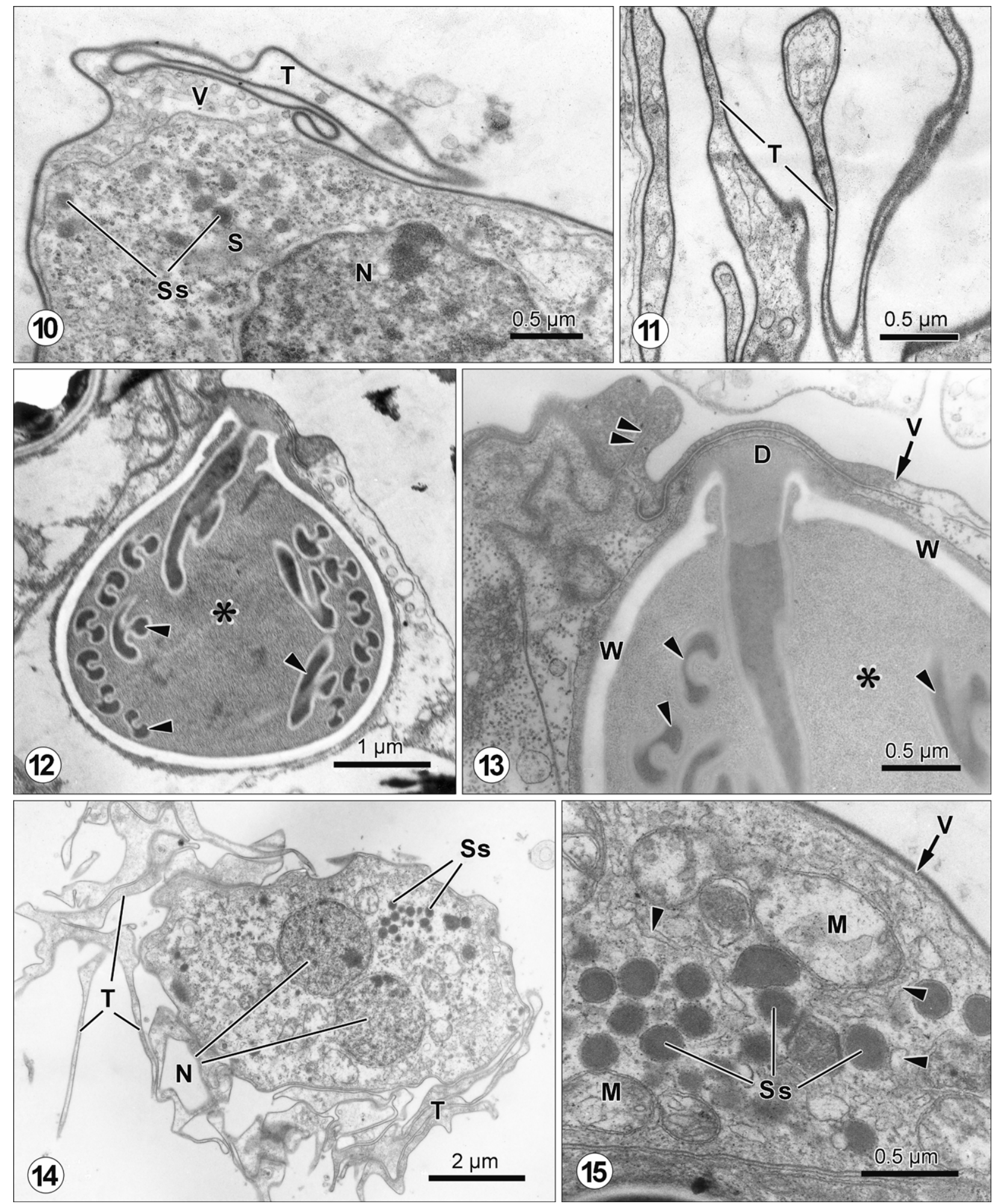

Figs. 10-15. Transmission electron micrographs of Ceratomyxa tenuispora. Fig. 10. Detail of valve (V), its tail (T) and the sporoplasm (S) with a nucleus (N) and some sporoplasmosomes (Ss). Fig. 11. Sections of spore tail (T) showing an electronlucid matrix. Fig. 12. Longitudinal section of a polar capsule with electron-dense matrix $(*)$, showing the polar filament sectioned at different levels (arrowheads). Fig. 13. Detail of the apical region of a polar capsule showing the wall (W), the channel for filament discharge (D), and some polar filament sections (arrowheads) within the capsular matrix (*). Externally, the valve (V) and the suture (double arrowhead). Fig. 14. Sporoplasm showing the two nuclei (N), several sporoplasmosomes (Ss) and several sections of the tails (T). Fig. 15. Detail of the sporoplasm showing several sporoplasmosomes (Ss), mitochondria (M) and some cisternae of endoplasmic reticulum (arrowheads). Externally, a surrounding valve (V) can be seen. 


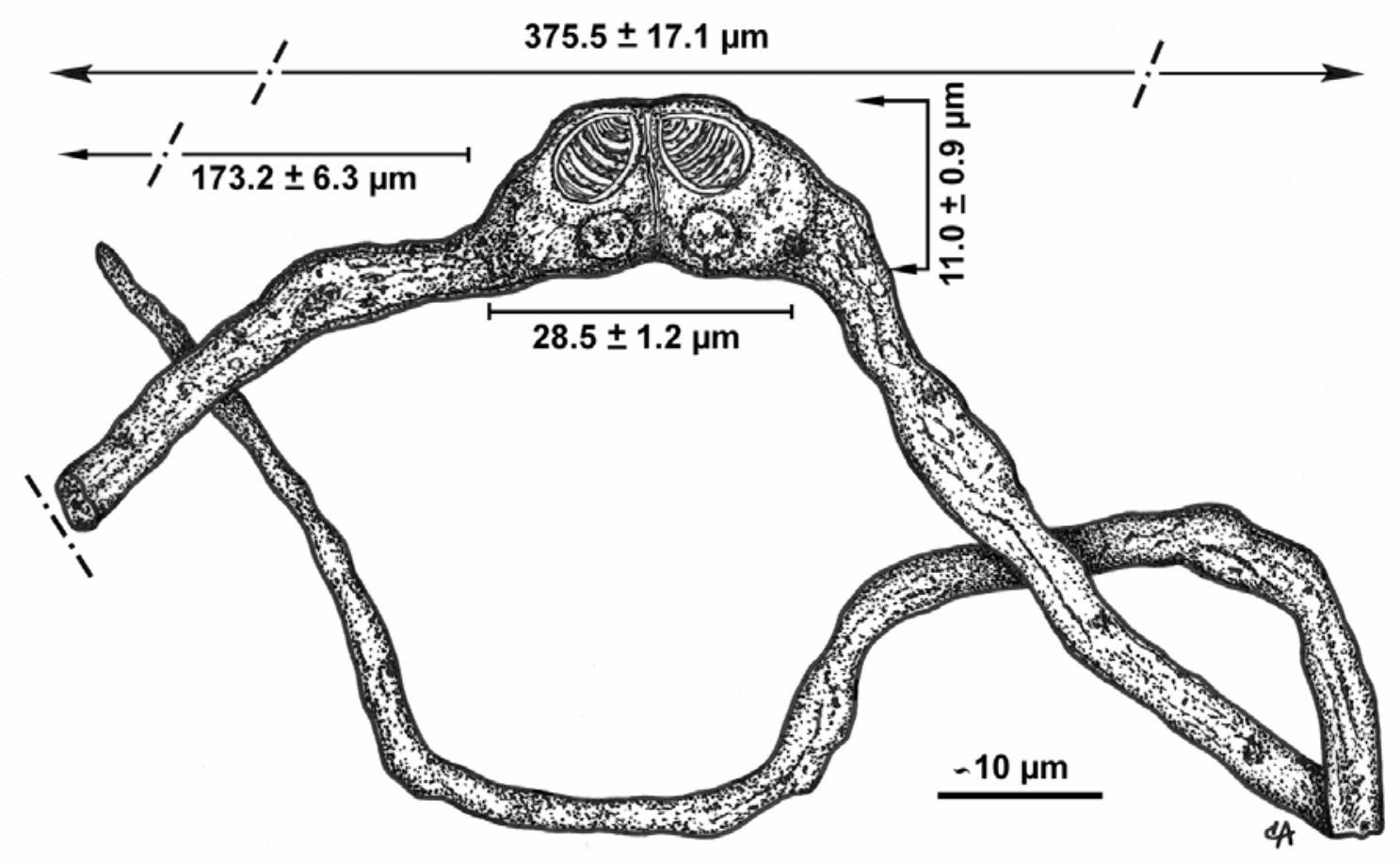

Fig. 16. Schematic drawing of Ceratomyxa tenuispora showing the spore morphology, with special emphasis on the two long tapering opposite lateral tails.

Table 1. Ceratomyxa tenuispora, comparison of spore characteristics between original description of Kabata (1960) and the present specimens (measurements in $\mu \mathrm{m}$ ).

\begin{tabular}{|c|c|c|}
\hline & Original description & Present material \\
\hline Host and organ & \multicolumn{2}{|c|}{ Aphanopus carbo, gall bladder } \\
\hline $\begin{array}{l}\text { Geographical } \\
\text { location }\end{array}$ & $\begin{array}{l}\text { Scotland } \\
\text { (United Kingdom) }\end{array}$ & $\begin{array}{l}\text { North Atlantic coast of Madeira Island } \\
\text { (Portugal) }\end{array}$ \\
\hline $\begin{array}{l}\text { Spore body } \\
\text { - length } \\
\text { - width } \\
\text { - thickness }\end{array}$ & $\begin{array}{l}\text { crescent-shaped with convex an } \\
8.7(8.4-9.8) \\
- \\
-\end{array}$ & $\begin{array}{l}\text { or end and flattened posterior end } \\
11.0 \pm 0.9 \\
12.1 \pm 1.1 \\
28.5 \pm 1.2\end{array}$ \\
\hline Total thickness & $387(308-504)$ & $375.5 \pm 17.1$ \\
\hline $\begin{array}{l}\text { Polar capsules } \\
\text { - length } \\
\text { - width }\end{array}$ & $\begin{array}{l}\text { two equal, sub-spherica } \\
6.4(5.6-7.0)\end{array}$ & $\begin{array}{l}\text { pyramidal } \\
5.2 \pm 0.3 \\
4.1 \pm 0.4\end{array}$ \\
\hline Polar filament & - & coils of 7 to 8 turns \\
\hline Sporoplasm & slightly granular with vacuoles & binucleate \\
\hline
\end{tabular}

More than 30 species of Ceratomyxa with long lateral processes have been described in different hosts and geographic areas (Sitjà-Bobadilla and Alvarez-Pellitero 1993a). Ceratomyxa tenuispora is the second longest of this Ceratomyxa spp. group. These processes have not been ultrastructurally described except for C. labracis (Sitjà-Bobadilla and Alvarez-Pellitero 1993a), showing similar ultrastructural aspects to those described in this study.

Since the description of $C$. tenuispora based on a drawing obtained from LM observations by Kabata (1960) and a later report by Costa et al. (1996), no other reports of this species have been published. The mor- phological and morphometrical characteristics of the spore seem to be the same, except for total thickness, the present specimens being somewhat smaller than $C$. tenuispora studied previously (Kabata 1960, Costa et al. 1996). Also, the parasite was collected from the same host species (Aphanopus carbo) and the same organ (gall bladder) (Table 1).

Acknowledgements. This work was supported by the António de Almeida Foundation-Porto-Portugal and a CESPU (Cooperativa de Ensino Superior, Politécnico e Universitario) $\mathrm{PhD}$ grant. We would like to thank Mr. João Carvalheiro for technical assistance and to Dr. Victor Ferreira for helping in the English revision. The helpful suggestions and comments of the reviewers are greatly appreciated. 


\section{REFERENCES}

Alvarez-Pellitero P., SitjÀ-Bobadilla A. 1993: Pathology of Myxosporea in marine fish culture. Dis. Aquat. Org. 17: 229-238.

CANNing E.U., CuRry A., ANDERSON C.L., OKAMura B. 1999: Ultrastructure of Myxidium trachinorum sp. nov. from the gallbladder of the lesser weever fish Echiichthys vipera. Parasitol. Res. 85: 910-919.

CASAL G., MAtos E., AZEVEDO C. 2002: Ultrastructural data of the spore of Myxobolus maculatus n. sp. (Phylum Myxozoa), parasite from the Amazonian fish Metynnis maculatus Kner, 1860 (Teleostei). Dis. Aquat. Org. 51: 107-112.

ChO J.B., KwON S.R., KIM S.K., NAM Y.K., KIM K.H. 2004: Ultrastructure and development of Ceratomyxa protopsettae Fujita, 1923 (Myxosporea) in the gallbladder of cultured olive flounder, Paralichthys olivaceus. Acta Protozool. 43: 241250 .

Costa G., Eiras J.C., Chubb J., MacKenzie K., Berland B. 1996: Parasites of the black scabbard fish, Aphanopus carbo Lowe, 1839 from Madeira. Bull. Eur. Assoc. Fish Pathol. 16: $13-16$.

CURRENT W.L. 1979: Henneguya adiposa Minchew (Myxosporida) in the channel catfish: ultrastructure of the plasmodium wall and sporogenesis. J. Protozool. 26: 209-217.

DESPORTES I., THEODORIDES J. 1982: Données ultrastructurales sur la sporogenèse de deux myxosporidies rapportées aux genres Leptotheca et Ceratomyxa parasites de Merluccius merluccius (L.) (Téléostéen Merluciidae). Protistologica 18: 533-557.

DiAMANT A., PAPERNA I. 1989: Cytopathology of Ceratomyxa sp. (Myxosporea) hyperparasitized with the microsporidan Nosema ceratomyxae. Dis. Aquat. Org. 6: 75-79.

DIAMANT A., PAPERNA I. 1992: Zschokkella icterica sp. nov. (Myxozoa, Myxosporea), a pathogen of wild rabbitfish $\mathrm{Si}$ ganus luridus (Ruppell, 1829) from the Red Sea. Eur. J. Protistol. 28: 71-78.

EIRAS J.C. 2006: Synopsis of the species of the genus Ceratomyxa Thélohan, 1892 (Myxozoa: Myxosporea: Ceratomyxidae). Syst. Parasitol. 65: 49-71.

KABATA Z. 1960: On two myxosporidian parasites of marine fishes, including one new species (Ceratomyxa tenuispora). Ann. Mag. Nat. Hist. 13: 305-306.

LOM J. 1969: Notes on the ultrastructure and sporoblast development in fish parasitizing myxosporidian of the genus Sphaeromyxa. Z. Zellforsch. 97: 416-437.
LOM J., DYKOVÁ I. 1992: Protozoan Parasites of Fishes. Developments in Aquaculture and Fisheries Science. Vol. 26. Elsevier, Amsterdam, $315 \mathrm{pp}$.

LOM J., DYKOVÁ I. 2006: Myxozoan genera: definition and notes on taxonomy, life-cycle terminology and pathogenic species. Folia Parasitol. 53: 1-36.

LoM J., FeIST S.W., DyKovÁ I., KePR T. 1989: Brain myxoboliasis of bullhead, Cottus gobio L., due to Myxobolus jiroveci sp. nov.: light and electron microscope observations. J. Fish Dis. 12: 15-27.

Morrison C.M., Martell D.J., LegGiardo C., O’Neil D. 1996: Ceratomyxa drepanopsettae in the gallbladder of Atlantic halibut, Hippoglossus hippoglossus, from the Northwest Atlantic Ocean. Folia Parasitol. 43: 20-36.

Palenzuela O., SitjÀ-Bobadilla A., Alvarez-Pellitero P. 1997: Ceratomyxa sparusaurati (Protozoa: Myxosporea) infections in cultured gilthead sea bream Sparus aurata (Pisces: Teleostei) from Spain: aspects of the host-parasite relationship. Parasitol. Res. 83: 539-548.

Rocha E., MATOS E., AZEVEDO C. 1992: Henneguya amazonica n. sp. (Myxozoa, Myxobolidae), parasitizing the gills of Crenicichla lepidota Heckel, 1840 (Teleostei, Cichlidae) from Amazon river. Eur. J. Protistol. 28: 273-278.

SitjÀ-Bobadilla A., AlvareZ-Pellitero P. 1993a: Light and electron microscopical description of Ceratomyxa labracis $\mathrm{n}$. sp. and a redescription of $C$. diplodae (Myxosporea: Bivalvulida) from wild and cultured Mediterranean sea bass Dicentrarchus labrax (L.) (Teleostei: Serranidae). Syst. Parasitol. 26: $215-223$.

SitjÀ-Bobadilla A., Alvarez-Pellitero P. 1993b: Zschokkella mugilis $\mathrm{n}$. sp (Myxosporea: Bivalvulida) from mullets (Teleostei: Mugilidae) of Mediterranean waters: light and electron microscopic description. J. Eukaryot. Microbiol. 40: 755-764.

Sitjà-Bobadilla A., Palenzuela O., Alvarez-Pellitero P. 1995: Ceratomyxa sparusaurati n. sp. (Myxosporea: Bivalvulida), a new parasite from cultured gilthead seabream (Sparus aurata L.) (Teleostei: Sparidae): light and electron microscopic description. J. Eukaryot. Microbiol. 42: 529-539.

YAMAMOTO T., SANDERS J.E. 1979: Light and electron microscopic observations of sporogenesis in the Ceratomyxa shasta (Noble, 1950). J. Fish Dis. 2: 411-428. 